\title{
Disteniinae Thomson (Insecta, Coleoptera): a protected name
}

\author{
Miguel A. Monné ${ }^{1,2} \&$ Antonio Santos-Silva ${ }^{3}$
}

\author{
${ }^{1}$ Museu Nacional, Universidade Federal do Rio de Janeiro, Quinta da Boa Vista, São Cristóvão, 20940-040 Rio de Janeiro-RJ, Brazil. \\ monne@uol.com.br \\ ${ }^{2}$ Bolsista do CNPq \\ ${ }^{3}$ Museu de Zoologia, Universidade de São Paulo, Av. Nazaré, 481, 04299-970 São Paulo-SP, Brazil. toncriss@uol.com.br
}

\begin{abstract}
Disteniinae Thomson (Insecta, Coleoptera): a protected name. The name "Cométites" Blanchard, 1845 (= Cometinae) is considered nomen oblitum, and "Distenitae" Thomson, 1861 (=Disteniinae), nomen protectum, under the provisions of the Article 23.9 of the ICZN. Disteniinae is hereafter used as a valid family-group name.
\end{abstract}

KEYWORDS. Cerambycidae; Cométites; nomenclature; nomen oblitum; nomen protectum.

RESUMO. Disteniinae Thomson (Insecta, Coleoptera): um nome válido. O nome Cométites Blanchard, 1845 (=Cometinae) é considerado nomen oblitum, e "Distenitae" Thomson, 1861 (=Disteniinae), nomen protectum, conforme o Artigo 23.9 do ICZN. Disteniinae é doravante utilizado como um nome válido do grupo-família.

PALAVRAS-CHAVE. Cerambycidae; Cometites; nomenclatura; nomen oblitum; nomen protectum.

Blanchard (1845: 163) used the name "Cométites" for a group of genera within the family "Lepturides" in which included: Distenia Lepeletier \& Audinet-Serville, 1825, Phelocalocera Blanchard, 1845, and Cometes Lepeletier \& Audinet-Serville, 1825. Except for Heteropalpus Buquet, 1843 (genus not mentioned in Blanchard's work), the "Cométites" included all genera known at that time and that currently belong to Disteniinae (Coleoptera, Cerambycidae). At the present time all these old family-group names received the appropiate suffixes, e. g. "Lepturides" Latreille, $1804=$ subfamily Lepturinae, and the tribes of Blanchard (l. cit.) "Eburites" = Eburiini, "Callichromites" = Callichromatini, "Xystrocérites" = Xystrocerini.

Thomson (1861: 181) named "Distenitae" for his fifth group ("Cerambycitae Verae"), that included the genera Distenia, Cometes and Noemia Pascoe, 1856. The genus Heteropalpus was mentioned as probably belonging to the group. Cyrtonops White, 1853 was not included in Thomson's work and Dynamostes Pascoe, 1857, mentioned at page 379, was not allocated in any group.

The definition of the level within the family-group has been a controversial issue since the century XIX. The following allocations are some examples: Disteniini (tribe of Cerambycinae, Cerambycidae) according to LeConte (1873: 323), LeConte \& Horn (1883: 307), Plavilstshikov (1931:3), Saalas (1936: 51) and Blackwelder (1946: 557); Disteniinae subfamily of Cerambycidae, according to Knull (1946: 150), Kojima \& Hayashi (1969: 6), Crowson (1955: 141), Quentin \& Villiers (1980: 32) and Lawrence \& Newton (1995: 787); Disteniidae family of Coleoptera, according to Mann \& Crowson (1981: 738), Monné \& Giesbert (1994: 301), Martins \& Galileo (1994: 77), and Makihara et al. (2002: 190).

Santos-Silva \& Hovore (2007) considered Disteniinae as nomen protectum, and "Cométites" as nomen oblitum.
However, the authors did not base the proposition in accordance with the Article 23.9 of the Code (ICZN 1999).

Although the name "Distenitae" is a junior synonym, the name "Cométites" was not used after 1869 (formally), having been mentioned a single time by Lacordaire (1869: 231) in a note. Then, the condition demanded concerning the lack of usage of a senior synonym after 1899 by Article 23.9.1.1 of the Code (ICZN op.cit.) is met.

To satisfy the requirements of the Article 23.9.1.2 of the Code (ICZN op.cit.), we present th following published works:

Adlbauer, K. 2004. Neue Disteniidae und Cerambycidae aus Afrika und den Seychellen (Coleoptera). Les Cahiers Magallanes 37: 117. (p. 2: Disteniidae).

Aurivillius, C. 1912. Coleopterorum Catalogus, pars 39, Cerambycinae. Berlin, W. Junk, 574 p. (p. 7: Disteniini).

Boppe, P. L. 1921. Genera Insectorum, Fam. Cerambycidae: subfam. Disteniinae-Lepturinae P. Wytsman, Bruxelles, 178, 1-119. (p. 2: Disteniinae).

Craighead, F. C. 1923. North American cerambycid-larvae. Bulletin of the Canada Department of Agriculture (n.s.) 27: 1-239. (p. 99: Disteniinae).

Chemsak, J. A.; E. G. Linsley \& F. A. Noguera. 1992. Listados Faunisticos de Mexico II. Los Cerambycidae y Disteniidae de Norteamerica, Centroamerica y las Indias Occidentales (Coleoptera). Universidad Nacional Autónoma de Mexico, Instituto de Biologia, México, 204 p. (p. 163: Disteniidae).

Ehara, S. 1954. Comparative anatomy of male genitalia in some cerambycid beetles. Journal of the Faculty of Agriculture, Hokkaido University, Zoology 12(1/2): 61-115. (p. 70: Disteniinae).

Ferreira, M. C. \& G. V. Ferreira. 1959. Catálogo dos Cerambicídeos da Região Etiópica. II Parte - Supertribos Disteniina, Asemina, Cerambycina, Auxesina \& Lepturina. Memórias do Instituto de Investigações Científicas de Moçambique 1: 77-398. (p. 77: Disteniina).

Gahan, C. J. 1906. Coleoptera (Cerambycidae). The Fauna of British India, including Ceylon and Burma. C. T. Bingham London, xviii +329 p. (p. 58: Disteniinae).

Gressitt, J. L. 1940. The Longicorn beetles of Hainan Island Coleptera: 
Cerambycidae. Philippine Journal of Science 72(1-2): 1-239. (p. 26: Disteniinae).

Gressitt, J. L. \& J. A. Rondon. 1970. Cerambycids of Laos (Disteniidae, Prioninae, Philinae, Aseminae, Lepturinae, Cerambycinae). Pacific Insects Monograph 24: 1-314. (p. 7: Disteniidae).

Kaoru, M.; S. Sato \& H. Miyata. 2002. Species diversity of longicorn beetles in humid warm-temperate forests: the impact of Forest management pratices on old-growth Forest species in southwestern Japan. Biodiversity and Conservation 11: 1919-1937. (p. 1919: Disteniidae).

Lawrence, J. F. 1991. Order Coleoptera. In: Stehr, F. W. (ed.). Immature Insects, Dubuque, Kendall/Hunt Publishing Co., 2: 144298. (p. 234: Disteniinae).

Lepesme, P. \& S. Breuning. 1952. Note preliminaire sur la classification des Coléoptères Cerambycides. Transactions of the IXth International Congress of Entomology 1: 139-142. (p. 139: Disteniina)

Linsley, E. G. 1962. The Cerambycidae of North America. Part III. Taxonomy and Classification of the subfamily Cerambycinae, Tribes Opsimini through Megaderini. University of California Publications in Entomology 20: 1-188. (p. 1: Disteniidae).

Matsushita, M. 1933. Beitrag zur Kenntnis der Cerambyciden des Japanischen Reichs. Journal of the Faculty of Agronomy, Hokkaido University 34(2): 157-445. (p. 167: Disteniinae).

Morvan, O. \& J. Morati. 2006. Contribution a la connaissance des Cerambycidae de la montagne de Kaw, Guyane Française (Coleoptera). Lambillionea 106(3) : 1-63. (p. 53: Disteniinae).

Reid, C. A. M. 1995. A cladistic analysis of subfamilial relationships in the Chrysomelidae sensu lato (Chrysomeloidea). In: J. Pakaluk \& S. A. Elipiñski (Eds.). Biology, Phylogeny, and Classification of Coleoptera. Papers Celebrating the $\mathbf{8 0}^{\text {th }}$ Birthday of Roy A. Crowson 2: 559-1092. (p. 563: Disteniidae).

Nakamura, S. 1981. Morphological and taxonomic studies of the Cerambycid pupae of Japan (Coleoptera: Cerambycidae). Miscellaneous Reports of the Hiwa Museum for Natural History 20: 1-159. (p. 13: Disteniinae).

Saito, A. 1990. Female Reproductive Organs of Cerambycid Beetles from Japan and the Neighbouring Areas I. Philini through Atimiini. Elytra 18(2): 231-260. (p. 236: Disteniidae).

Schiefer, T. L. 1998. A preliminary List of the Cerambycidae and Disteniidae (Coleoptera) of Mississippi. Transactions of the American Entomological Society 124(2): 113-131. (p. 128: Disteniidae).

Švácha, P. \& M. L. Danilevsky. 1987. Cerambycoid Larvae of Europe and Soviet Union (Coleoptera, Cerambycoidea). Part I. Acta Universitatis Carolinae - Biologica 30(1-2): 1-176. (p. 33: Disteniidae).

Švácha, P.; J.-J. Wang \& S.-C. Chen. 1997. Larval morphology and biology of Philus antennatus and Heterophilus punctulatus, and systematic position of the Philinae (Coleoptera: Cerambycidae and Vesperidae). Annales de la Société Entomologique de France (N.S.) 33(3): 323-369. (p. 323: Disteniidae).

Viana, M. J. 1972. Aporte al catálogo de Cerambycidae del Paraguay (Insecta, Coleoptera). Revista del Museo Argentino de Ciencias Naturales Bernardino Rivadavia (Entomología) 3(4): 207-405. (p. 234: Disteniini).

Villiers, A. 1980. Insectes Coléoptères Cerambycidae. Disteniinae. Faune de Madagascar 52: 1-133. (p. 5 : Disteniinae).

Yanega, D. 1996. Field Guide to Northeastern Longhorned Beetles (Coleoptera: Cerambycidae). Champaign, Illinois Natural History Survey, $x+174$ p. (p. 25: Disteniinae).

Conclusions. "Distenitae" Thomson, 1860 (=Disteniinae) is considered nomen protectum, and hereafter used as valid family-group name. "Cométites" Blanchard, 1845 (= Cometinae) on the other hand is nomen oblitum, consequently an invalid name.

\section{REFERENCES}

Blackwelder, R. E. 1946. Checklist of the coleopterous insects of Mexico, Central America, the West Indies and South America. Part 4. Bulletin of the United States National Museum 185: 551763.

Blanchard, C. E. 1845. Histoire des insectes, traitant de leurs moeurs et de leurs métamorphoses en général, et comprenant une nouvelle classification fondée sur leurs rapports naturels. Paris, Didot (Ed.), 2: 1-524

Crowson, R. A. 1955. The natural classification of the families of Coleoptera. London, Nathaniel Lloyd, 187 p.

ICZN. 1999. International Code of Zoological Nomenclature. London, $306 \mathrm{p}$

Kojima, K. \& M. Hayashi. 1969. Insect's life in Japan. Longicorn Beetles. Osaka, Hoikusha Publishing, 1: 1-295.

Knull, J. N. 1946. The long-horned beetles of Ohio (Coleoptera, Cerambycidae). Bulletin of the Ohio Biological Survey 39: $133-354$.

Lacordaire, J. T. 1869. Histoire Naturelle des Insectes. Genera des Coléoptères. Paris, Librairie Encyclopédique de Roret, 8: 1552 .

Lawrence, J. F. \& A. F. Newton, Jr. 1995. Families and subfamilies of Coleoptera (with selected genera, notes, references and data on family-group names). In: Biology, Phylogeny, and classification of Coleoptera: Papers Celebrating the $8^{\text {th }}$ Birthday of Roy A. Crowson. Warszawa, Pakaluk, J. \& S. A. Elipiñski (Eds.), 2 779-1007.

LeConte, J. L. 1873. Classification of the Coleoptera of North America. Prepared for the Smithsonian Institution. Part II. Smithsonian Miscellaneous Collections 1: 279-348.

LeConte, J. L. \& G. H. Horn. 1883. Classification of the Coleoptera of North America. Prepared for the Smithsonian Institution. Smithsonian Miscellaneous Collections 26: xxxvii +567 p.

Makihara, H.; W. A. Noerdjito \& Sugiarto. 2002. Longicorn beetles from Gunung Halimum National Park, West Java, Indonesia from 1997-2002 (Coleoptera, Disteniidae and Cerambycidae). Bulletin of the Forestry and Forest Products Research Institute 1 : $189-223$.

Mann, J. S. \& R. A. Crowson. 1981. The systematic position of Orsodacne Latr. And Syneta Lac. (Coleoptera, Chrysomelidae), in relation to characters of larvae, internal anatomy and tarsal vestitute. Journal of Natural History 15: 727-749.

Martins, U. R. \& M. H. M. Galileo. 1994. Novas espécies e notas sobre Cerambycidae e Disteniidae (Coleoptera) do Estado do Tocantins, Brasil. Iheringia, Zoologia 77: 77-82.

Monné, M. A. \& E. F.Giesbert. 1994. Checklist of the Cerambycidae and Disteniidae (Coleoptera) of the Western Hemisphere. Burbank, Wolfsgarden Books, $410 \mathrm{p}$.

Plavilstshikov, N. N. 1931. Cerambycidae. I. Teil. Cerambycinae: Disteniini, Cerambycini I (Protaxina, Spondylina, Asemina, Saphanina, Achrysonina, Oemina, Cerambycina). BestimmungsTabellen der europäischen Coleopteren 100: 1-102.

Quentin, R. M. \& A. Villiers. 1980. Insectes Coléoptères, Cerambycidae, Disteniinae. Faune de Madagascar 52: 1-134.

Saalas, U. 1936. Über das Flügelgeäder und die phylogenetische entwicklung der Cerambyciden. Annales Zoologici Societatis Zoologicae-Botanicae Fennicae Vanamo 4: 1-198.

Santos-Silva, A. \& F. T. Hovore. 2007. Divisão do gênero Distenia Lepeletier \& Audinet-Serville, notas sobre a venação alar em Disteniini, homonímias, sinonímia e redescrições (Coleoptera, Cerambycidae, Disteniinae). Papéis Avulsos de Zoologia 47: 129.

Thomson, J. 1861. Essai d'une classification de la famille des cérambycides et matériaux pour servir a une monographie de cette famille. Paris, Thomson ed., p. 129-396.

Received 10/09/2007; accepted 12/02/2008 